Gani Asllani*

Bedri Statovci ${ }^{* *}$
JEL Classification H2, H3, H6

Preliminary statement

\title{
EFFECT OF THE CHANGE IN VALUE ADDED TAX ON THE FISCAL STABILITY OF KOSOVO
}

The main goal of this paper is to analyse the effect of the change in tax rates for VAT for certain categories of goods on the fiscal stability of Kosovo. In Kosovo, VAT has been applied since 2001 and is an indirect tax on consumption that is the principal source of revenue to the state budget. The importance of this research paper is its focus on whether the changes made to the VAT rates in September 2015 have had positive or negative effects on some product prices, increasing or decreasing the state budget and the impact on the development of economic indicators expressed through GDP. The methodology of the paper is based on the comparative analysis of the data using both primary and secondary sources. The econometric model includes two variables and their relationships, independent variables, such as VAT, and dependent variables, like GDP. Through the econometric model and linear regression analysis for the period 2013-2016, the hypotheses have been tested with STATA application/software to calculate the impact of changes in the tax rate for VAT on the budget, economic growth and economic development. The results of the analysis show that the VAT reduction from 16\% to $8 \%$ for basic products and the increase in VAT from 16\% to $18 \%$ on luxury products had a positive effect on budget revenues and growth of GDP of Kosovo.

Key words: VAT rate, budget revenues, economic growth, taxation

* G. Asllani, Ph. D., Professor at Law Faculty, University "Haxhi Zeka”, Peja, Kosovo (E-mail:gani.asllani@unhz.eu).

** B. Satovci, Ph. D., Professor at Economic Faculty, University “Haxhi Zeka”, Peja, Kosovo (E-mail: bedri.statovci@unhz.eu).

The paper was received on February $23^{\text {rd }}, 2018$. It was accepted for publication on June $1^{\text {st }}$, 2018. 


\section{Introduction}

The state and its institutions are not able to exist and function without the payment of tax obligations by its citizens as well as enterprises, so tax is part and parcel of the existence of the state and the payment of taxes is mandatory. Kosovo has built and continues to build a simple tax system, the application of low tax rates along with a free trade model (barriers and customs restrictions), and is among the more liberal countries in the region, which enables rapid integration. The fiscal system in Kosovo is relatively new, and is based on direct and indirect taxes. Capacity building began in 1999 with the Regulation on Customs, followed by the application of other taxes such as: the presumptive tax (May 2000), VAT (May 2001), income tax (1 April 2002), property tax (June 2003), corporation tax (December 2004), road tax (March 2005), royalties taxes and the application of other non-tax revenues. Since January 2005, tax policies introduced initial tax amendments along with the application of new taxes such as Corporate Income Tax (CIT) as well as Personal Income Tax (PIT), and this continued until the end of 2008 .

In January 2009, a new law came into force, with a reduction in tax rates in Kosovo, also tax rates on dividends, interest, rent, gambling, capital gains, sale of intangible property, etc. were reduced from $20 \%$ to $10 \%$. However, VAT underwent a slight increase from $15 \%$ to $16 \%$, which in reality caused a small increase in prices in the country. In recent years, there has been continuous reform of the tax policy in Kosovo. Currently, the tax system in Kosovo is considered to be quite simple and harmonized.

\section{Literature review}

The experiences of many countries suggest that the application of taxes, especially VAT, affects the economy in different ways. Taxes, as the main and most important tool for collecting public revenues are presented in a variety of forms (Rimmler, Rose, \& Zöller, 2017). In Kosovo legislation, taxes are divided into direct and indirect taxes according to whether they are levied at the time of income generation or at the time of spending the income. Thus, according to this criterion, taxes paid on income generation represent the group of direct taxes, whereas those realized at the time of income spending are included in the group of indirect taxes (Jelcić, 1997). All preparations for the administration and operation of value added tax should enable the necessary conditions for the practical application of the legal regulation (Feld, 2005). Carrying out this task requires serious and considered 
action because any possible omission of any part of the administrative procedure will not only slow down and hamper the operation of the tax but could cause a loss of tax revenue (Cosanegro de Jantscher, 1990). Examining the impact of taxes on economic growth makes it possible to observe that the level of capital and intermediate goods tax has a significant effect on economic growth; countries with lower taxes grow faster than those applying high taxes (Gerson, 1998). In an analysis of the relationship between taxes and the rate of economic growth in the 23 OECD countries for the period 1965-1990, not relying on any argument that there is any correlation between the tax rate and economic growth, it was found to support the idea that taxes have a negative effect on economic growth (Eidmalm, 1999). The author concludes by means of econometric analysis that progressive taxation results in a higher negative effect on real GDP. High taxes reduce consumer incomes and limit their economic freedom in the short run, but may also reduce economic efficiency and welfare in the long-term. If expenditures were cut short this would immediately affect categories that benefit directly from government programmes (Vito, 1990). Given the size of the parameter, government revenues affect economic growth more than government spending. Economic growth is positively affected by productive and negative costs, but the first have a greater impact (Buturac, 2014). High corporate taxes discourage potential investors from realizing investments in the given country (Beker, 2009). Corporations use tax policy and tax rates as a means of attracting foreign investors (Vill \& Barreix, 2002). Fiscal policy measures can counter and improve the short-term difficulties driven by damaging trends in the economy (Genser, 2006). They can also eliminate the causes of these trends and establish stability with measures of stabilization policy. In addition to short-term flows, fiscal policy can be oriented to the long-term growth of GDP and per capita income, respectively. In this case, this relates to the rate of economic growth (Gallagher, \& Babič, 2004). Fiscal policy is the use of government expenditures and taxation to affect economic activity (Dubrowski, \& Magdalena, 2001).

\section{Data and methodology}

The purpose of the research is to analyse the effect of changes in VAT legislation with tax rates from $0-16 \%$ scaled to $0 \%, 8 \%$ and $18 \%$ on the comparative 2013-2016 GDP growth. Through the interconnection of variables, it is attempted to understand and identify the role of VAT on economic development. To this end, an econometric model was used to analyse the relationship between economic variables such as: GDP as dependent variable and VAT as independent variable. 


\section{Research Methodology}

For the purpose of developing this work, and to define the main concepts of value added tax (VAT), its elements and characteristics, comparative analysis methodology was adopted, using primary data and other secondary sources.

The research question

Will the macro-fiscal policies (VAT) affect the growth of economic development and the better collection of value added tax have a negative or positive effect on GDP?

\section{Hypotheses}

The hypotheses set out are: Hypothesis $\mathrm{H} 0$ and $\mathrm{H} 1$ :

$H O=$ Value added tax has a negative effect on the growth of economic development reducing GDP

$H 1=$ Value added tax has a positive effect on economic growth, increasing GDP.

\section{Value added tax in Kosovo (VAT)}

Value added tax (VAT) has been applied to imports and domestic supplies of goods and services since 1 July 2001 (according to UNMIK Regulation No. 2001/11 "On Value Added Tax" which was amended by UNMIK Regulation No. $2002 / 17$ and 2004/35). It was applied at the rate of $15 \%$ and with a zero scale $(0 \%)$. Entities that are to be registered as taxable persons are persons with annual turnover over 50,000 $€$ (and those who are under the threshold but who choose to be registered for VAT). Such entities apply and collect the VAT calculated by their buyers or customers and receive a lump-sum credit for the VAT paid on their domestic imports and purchases. Where the deductible VAT of the requested VAT exceeds the calculated tax on the VAT collected, the taxable person will have the right to lend VAT. Value added tax includes the application of total tax on goods and services consumption, which is exactly proportional to the price of the goods and services. VAT is calculated at this rate according to the applicable rate, is charged at different stages of production, distribution and the lifecycle of goods and services trade, and is ultimately charged to the customer. In 2008, the tax rates changed from $15 \%$ and $0 \%$ to $16 \%$ and $0 \%$, this change was in force until the new changes that were made in 2015. In September of this year, the reform of the 
VAT legislation was reformulated, among other changes made, the main ones are: a) The standard VAT rate increased from $16 \%$ to $18 \%$, b) The reduced VAT rate fell to $8 \%$ from $16 \%$, c) For goods / services the assigned tax rate is $8 \%$, d) The VAT threshold for VAT registration was reduced from $€ 50,000$ to $€ 30,000$, e) The period for VAT registration was the calendar year (January - December), f) It included the treatment of bad debt, g) The list of goods exempt VAT (raw materials and machinery) was expanded.

\section{Case study - the impact of VAT changes in Kosovo}

The case study shows the impact of VAT on the country's economy, revenue growth and GDP in the years 2013-2016. Taking the change in the VAT legislation in 2015 as a case study, we will see how much this change has affected the state budget as well as the basket of consumer goods. Also by analysing and processing the data using STATA software, we will answer the research question and see if the hypotheses are proved or disproved.

The Kosovo Tax Administration during 2013-2016 achieved significant results by realizing revenues that have passed the plan (compared to previous periods). The progress achieved refers to the provision of voluntary relief facilities, equal treatment of all taxpayers, and successful implementation of revenue collection planning.

The success achieved refers to the provision of professional, transparent and effective services and through the fair and uniform implementation of tax laws, the modernization of the large taxpayer unit, the extension of functions at the call centre, the development of online tax declarations, and increasing the capacities in the risk management unit and the tax investigation unit. The Tax Administration of Kosovo has realized higher revenues from year to year by increasing voluntary compliance with tax obligations, as well as reducing the cost to taxpayers in performing their tax obligations. 
Table 1.

STRUCTURE OF REVENUES (2011-2015) IN MILLION EUROS

\begin{tabular}{|c|c|c|c|c|c|r|r|}
\hline Tax & $\mathbf{2 0 1 1}$ & $\mathbf{2 0 1 2}$ & $\mathbf{2 0 1 3}$ & $\mathbf{2 0 1 4}$ & $\mathbf{2 0 1 5}$ & $\begin{array}{c}\text { Comp. } \\
\mathbf{2 0 1 4} \\
\mathbf{2 0 1 5}\end{array}$ & $\begin{array}{l}\text { For } \\
\text { year } \\
\mathbf{2 0 1 5}\end{array}$ \\
\hline 1 & 2 & 3 & 4 & 5 & 6 & $7=6 / 5$ & 8 \\
\hline VAT & $122,327,310$ & $131,394,869$ & $149,184,989$ & $136,939,023$ & $153,877,977$ & $112 \%$ & 46.3 \\
\hline Cor. Tax & $58,155,213$ & $65,138,976$ & $65,924,380$ & $65,818,313$ & $74,639,926$ & $113 \%$ & 22.5 \\
\hline Real Tax & $80,640,640$ & $87,365,088$ & $90,342,564$ & $100,937,655$ & $103,763,147$ & $103 \%$ & 31 \\
\hline Total & $261,123,163$ & $283,898,932$ & $305,451,932$ & $303,694,991$ & $332,281,049$ & $109 \%$ & 100 \\
\hline
\end{tabular}

Source: TAK- Annual reports for 2011-2015

In the structure of revenues by type of taxes by year, the largest share has been VAT amounting to more than $45.1 \%$, tax withholding at $22.3 \%$, corporate tax with $18.2 \%$, individual business tax with $10.8 \%$, tax on interest, dividends, property rights, lottery winnings and gambling 3.5\%, preliminary tax with $0.05 \%$ and profit tax with $0.01 \%$. In 2015 , VAT changed, with the main change being the exemption of raw materials used in the production process and a reduction of $8 \%$ for a product group, along with an increase from $16 \%$ to $18 \%$ for luxury goods. In revenues by main tax groups, the largest share for 2015 was value added tax with $46.3 \%$. By analysing the prices of some basic products over the years 2013-2016, we will see how much the change in VAT has affected the price of these products, which are reflected directly in the consumer basket, thus in GDP. This analysis involves dividing products into two groups, basic products for which the VAT rate has dropped from $16 \%$ to $8 \%$, and the second group that includes luxury goods for which the VAT rate has increased from $16 \%$ to $18 \%$. 
Table 2.

PRICES OF SOME BASIC PRODUCTS OVER FOUR YEARS

\begin{tabular}{|l|c|c|c|c|c|}
\hline Designation & Quantity & $\mathbf{2 0 1 3}$ & $\mathbf{2 0 1 4}$ & $\mathbf{2 0 1 5}$ & $\mathbf{2 0 1 6}$ \\
\hline Oils & $1 \mathrm{~kg}$ & 1.53 & 1.15 & 1.15 & 1.16 \\
\hline Wheat flour & $1 \mathrm{~kg}$ & 0.40 & 0.39 & 0.38 & 0.39 \\
\hline Meat & $1 \mathrm{~kg}$ & 6.80 & 6.85 & 6.95 & 7.00 \\
\hline Milk & 11. & 0.91 & 0.92 & 0.90 & 0.91 \\
\hline Sugar & $1 \mathrm{~kg}$ & 0.77 & 0.76 & 0.66 & 0.68 \\
\hline
\end{tabular}

Source: Statistical Yearbook of the Republic of Kosovo

Table 3.

PRICES OF SOME LUXURY PRODUCTS OVER FOUR YEARS

\begin{tabular}{|l|c|c|c|c|c|}
\hline Designation & Quantity & $\mathbf{2 0 1 3}$ & $\mathbf{2 0 1 4}$ & $\mathbf{2 0 1 5}$ & $\mathbf{2 0 1 6}$ \\
\hline Beer & 11. & 0.58 & 0.61 & 0.61 & 0.66 \\
\hline Alcohol & 11. & 8.55 & 8.55 & 8.71 & 8.78 \\
\hline Cigarettes & 1 packet & 1.16 & 1.22 & 1.33 & 1.40 \\
\hline Roasted coffee & $1 \mathrm{~kg}$ & 7.04 & 7.10 & 7.07 & 7.09 \\
\hline
\end{tabular}

Source: Statistical Yearbook of the Republic of Kosovo

\section{Empirical Analysis of VAT effects on GDP}

Following the specification of the log-log model and the valuation method, the data were analysed in the empirical work, calculated from the model and the results interpreted. Finally, the validity of the hypotheses defined in the research were verified.

Specification of the econometric model and log-log evaluation (OLS):

Through the simple linear regression method and the log-log method applications, the effects of VAT on GDP in the Republic of Kosovo have been tested. Therefore, the specification of the linear dimmed regression model is as follows: 


$$
Y=B 1+B 2+U i \text { Or } Y(G D P)=+B 1 B 2(V A T)+U I
$$

The specification of the linear dimmed regression model for 2013-2016 is as follows:

Y - represents the dependent variables (variables that are clarified, regressant, endogenous, predicted, etc.), in the case of this research the dependent variable is GDP.

$\mathrm{X}$ - represents the independent variable (regressor, exogenous, predicting, etc.), in this case the independent variable is: B1- the constant parameter, whereas B2- are the parameters of the independent variables assessment or the valuation coefficients, Ui - is stochastic or error term variables (contains all the factors or variables that are not foreseen in the model and is a random variable, receives positive and negative values). In calculating the regression, data on GDP and VAT were taken from the Central Bank of Kosovo, the financial reports of the Ministry of Finance, the World Bank, and the Kosovo Statistics Office. Given the limited access to the data required for this model, data interpolation is made at certain time periods relevant for 2013-2015.

\section{Figure 1.}

\section{GRAPH OF REVENUE AND GDP DATA}
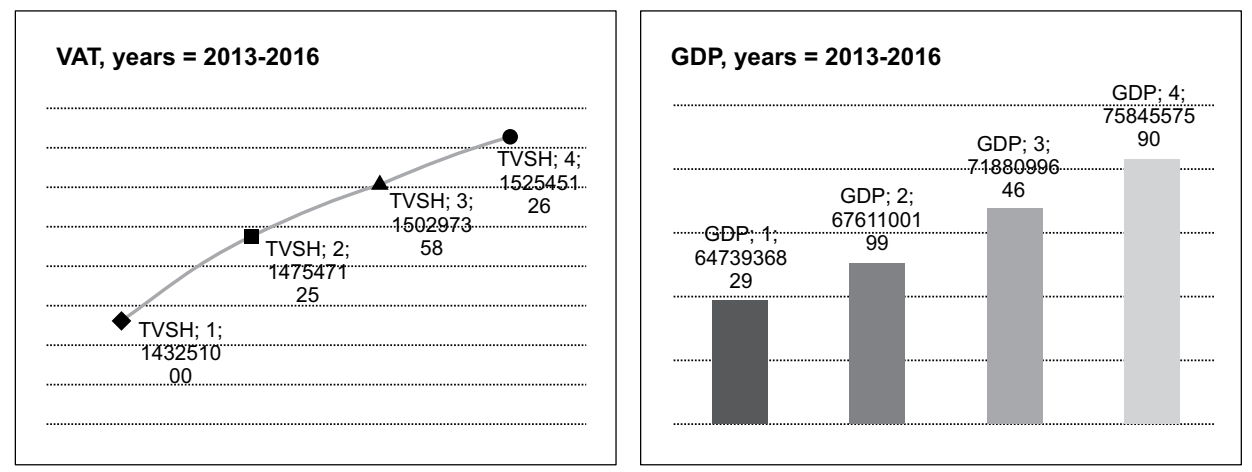

Source: Tax Administration of Kosovo, 2016

Through regression analysis we aimed to check the validity of the hypotheses set out at the beginning of this paper. In the model are included two variables, independent variables, exogenous such as VAT, and dependent variables, the regressant in our case is GDP. Below, we will specify the model as a regression to obtain the calculation. 
The econometric model (1) can be written as: $Y=61+62 X+\boldsymbol{u}$

Correlation calculation, the correlation coefficient of the sample is 0.97 positive. This correlation coefficient shows that there is a positive linear relationship between GDP and VAT.

\section{Linear Model with constant}

$\mathrm{B} 1=$ is the constant estimator parameter, which explains that the value -1.06 indicates the average value of GDP when VAT is zero.

$\mathrm{B} 2=118.58$, if VAT increases by $1 \%$ then GDP decreases on average to $-1.06 \%$

\section{Linear Model without constant}

B2 $=$ is a coefficient of estimation which shows the average VAT growth of $1 \%$ then on average will affect the GDP growth of $47.22 \%$

Specification of the results of the following two models, the difference between the two models:

The pattern based on the constant model is -1.06 , whereas the model with no constant value is 47.22 since the model without constant is better (clarifies the model with a high \%). Based on the results of both estimating models, the first model with constant has negative values, so the non-constant model has a very high positive ratio and accept the second model. The coefficient of corruption between the two models has a very small difference and the bargaining will not be interpreted because the independent variable clarifies dependently on an average of $0.97 \%$.

Estimates of the test on the constant model, and the F-test in these models shows us hypothesis $H O$ and supports $H 1$.

$H O=$ Value added taxes have adverse effects on the growth of economic development that affect the reduction of GDP.

$H 1=$ Value added taxes have a positive effect on the growth of the economic development, affecting the growth of GDP.

Regarding the test in question, at the significance level of 0.05 , the F-test 37.45 is of significance because it is larger than 4 .

$$
\text { GDP }=-1.06 .+118 . \mathrm{VAT}
$$

(se) $\quad 6287$

(t) 
Calculation of the evaluation coefficients in model (1) and the interpretation of the obtained results:

$$
\text { LogVAT }=13.46(\text { const }) 0.282(\text { lncigarettes })+0.003(\text { lnalcohol })+0.221
$$

Coefficient $\mathrm{B} 1=$ is constant when $\mathrm{x} 1$ and $\mathrm{x} 3$ are zero. Coefficient $\mathrm{B} 2=$ 0.282 , indicates that the increase of $1 \%$ of tobacco will effect on average $0.282 \%$ of the increase in VAT. Coefficient B3 $=0.003$, indicates that the increase of $1 \%$ of alcoholic beverages will have an average effect of $0.003 \%$ on the increase of VAT.

The empirical research results suggest that the impact of tobacco and alcoholic beverages have a major effect on VAT. If all the coefficients are collected, we gain 0.506, which shows that Economic Development in Kosovo has an average increase in yields. Based on the t-test the evaluation coefficients have significance.

Calculation of the evaluation coefficients in model (2) and the interpretation of the obtained results. LogVAT $=12.43$ (const) $0.000($ lnalcohol $)+0.382($ lnmeat $)$ $+2.648$

Coefficient $\mathrm{B} 1=$ is constant when $\mathrm{x} 1$ and $\mathrm{x} 3$ are zero

Coefficient B2 $=0.000$, indicates that the increase for $1 \%$ of alcoholic beverages will affect on average $0.000 \%$ increase in VAT.

Coefficient B3 $=0.382$, indicates that the increase of $1 \%$ of meats will have an average impact of $0.382 \%$ on the increase in VAT. The empirical research results suggest that the influence of alcoholic beverages and meats have a major effect on VAT. If all the coefficients are collected, we gain 3.03, which shows that the economic level in Kosovo has an increase above the average yield level because it is larger than 1 .

Calculation of the evaluation coefficients in model (3) and the interpretation of the obtained results.

$$
\begin{gathered}
\operatorname{LogVAT}=13.75(\text { const }) 0.39(\text { lnmill })+0.49(\text { lnsugar })+0.028(\text { lnnutrients })-0.84 \\
(\text { lnmilk })+0.66
\end{gathered}
$$

Coefficient $\mathrm{B} 1=$ is constant when $\mathrm{x} 1$ and $\mathrm{x} 5$ are zero. Coefficient $\mathrm{B} 2=0.39$, indicates that growth by $1 \%$ of wheat flour will have an average impact on $0.39 \%$ increase in VAT. Coefficient B3 $=0.49$, indicates that the growth of $1 \%$ of sugar will have an average impact of $0.49 \%$ on VAT growth. Coefficient B4 $=0.028$, indicates that growth by $1 \%$ of nutrients will affect on average $0.028 \%$ in VAT growth. The coefficient B5 $=-0.84$, indicates that the increase for $1 \%$ of milk will affect on average $-0.84 \%$ in the reduction of VAT. 
The empirical research results suggest that the impact of wheat flour, sugar, nutrition and milk has a huge effect on VAT. If all the coefficients are collected we earn 0.73, which shows that the economic level in Kosovo has an average increase in yields. Therefore, based on the econometric analysis, changes in VAT have had a positive effect, which has affected GDP growth in Kosovo. Through the econometric model, the effects of VAT on the GDP ratio were tested, where two elementary and elemental product classifications were made. In the product group, VAT movements have had a high effect on the average at 3.03\%. The econometric analysis in the elementary product group shows that the VAT reduction from $18 \%$ to $8 \%$ had a positive effect that affected the growth of GDP by $0.73 \%$.

\section{Commentary on the model}

Based on the results obtained by calculating the data with STATA-13, through the log-log model, the results obtained will be computed as follows: therefore they only represent the impact of value added taxes such as the variables, tobacco, and alcoholic beverages as independent variables. Interpretation of $\mathrm{r} 2 \rightarrow 0.998 » 99.8 \%$, reflects that the determination coefficient is high with $99.8 \%$, which means that the independent variable clarifies for $99.8 \%$, the dependent variable. Referring to the results we see that from $p>$ to the alpha $(\alpha)$ interval of 0.05 , the higher significance has cons because it approaches 0.05 with 0.010 , while the others are larger. Prob $>$ F 0.0359 means that with $36 \%$ we reject $\mathrm{H} 0 \rightarrow$. $\mathrm{H} 0=$ Value added taxes have adverse effects on the growth of economic development that affect the reduction of GDP. H1 = Value added taxes have a positive effect on economic growth, affecting the growth of GDP. On the basis of the results obtained by calculating the data with STATA-13, through the log-log model, the obtained results will be commented on as follows: therefore they only represent the impact of value added taxes such as the variables, sugar, nutritious oils and cucumber as independent variables. Interpretation of $\mathrm{r} 2 \rightarrow 0.99 \%$ reflects that the determination coefficient is high at $99 \%$, which means that the independent variable clarifies for $99 \%$, the dependent variable. Referring to the results we see that from $p>$ to alpha $(\alpha)$ interval of 0.05 , the higher significance has cons because it approaches 0.05 with 0.031 , while others are larger. Prob > F 0.069 means that with $69 \%$ we reject $\mathrm{H} 0 \rightarrow$. H0 $=$ Value added taxes have adverse effects on the growth of economic development that affect the reduction of GDP. H1 = Value added taxes have a positive effect on the growth of the economic development, which affects the growth of GDP. 
Table 4.

\section{GDP AND VAT}

\begin{tabular}{|c|c|c|c|}
\hline & Year & VAT & GDP \\
\hline 1 & 2013 & 143251 & $6.50+06$ \\
\hline 2 & 2014 & 147547 & $6.80+06$ \\
\hline 3 & 2015 & 150297 & $7.20+06$ \\
\hline 4 & 2016 & 152545 & $7.60+06$ \\
\hline Correlations GDP (obs-4) & GDP & VAT \\
\hline \multicolumn{2}{|c|}{ GDP } & 1.0000 & 1.0000 \\
\hline \multicolumn{2}{|c|}{ VAT } & 0.9743 & \\
\hline
\end{tabular}

Source: STATA data

Table 5.

\section{LUXURY PRODUCTS (TOBACCO, ALCOHOLIC BEVERAGES, MEAT)}

\begin{tabular}{|c|c|c|c|c|c|c|}
\hline Source & SS & df & MS & & \multicolumn{2}{|c|}{ Number of obs $=4$} \\
\hline Model & .0021976 & 2 & .0010988 & \multirow{2}{*}{\multicolumn{3}{|c|}{$\begin{array}{r}F(2,1)=386.96 \\
\text { Prob }>F=0.0359\end{array}$}} \\
\hline Residual & $2.8396 \mathrm{e}-06$ & 1 & $2.8396 \mathrm{e}-06$ & & & \\
\hline Total & .00220044 & 3 & 0.00073348 & \multirow{2}{*}{\multicolumn{3}{|c|}{$\begin{aligned} \text { R-squared } & =0.9987 \\
\text { Adj R-squared } & =0.9961 \\
\text { Root MSE } & =.00169\end{aligned}$}} \\
\hline & & & & & & \\
\hline InVAT & Coef. & Std. Err. & $\mathrm{t}$ & $\mathrm{P}>\mathrm{t}$ & \multicolumn{2}{|c|}{ (95\% conf. interval) } \\
\hline Inalcohol. & .0034938 & .0125489 & 0.28 & 0.827 & -.1559547 & .1629423 \\
\hline Intobacco & .28266547 & .02012204 & 13.98 & 0.045 & .0257298 & .5395796 \\
\hline -cons & 13.47635 & .2218792 & 60.74 & 0.010 & 10.65711 & 16.2956 \\
\hline Source & SS & df & MS & \multicolumn{3}{|c|}{ Number of obs $=4$} \\
\hline Model & .002027423 & 2 & .001013712 & & \multirow{4}{*}{\multicolumn{2}{|c|}{$\begin{aligned} \mathrm{F}(2,1) & =5.86 \\
\text { Prob }>\mathrm{F} & =0.2804 \\
\mathrm{R}-\mathrm{squared} & =0.9214 \\
\text { Adj R-squared } & =0.7641 \\
\text { Root MSE } & =.01315\end{aligned}$}} \\
\hline Residual & $.00173 \mathrm{e}-16$ & 1 & .000173016 & & & \\
\hline Total & .00220044 & 3 & .00073348 & & & \\
\hline & & & & & & \\
\hline InVAT & Coef. & Std. Err. & $\mathrm{t}$ & $\mathrm{P}>\mathrm{t}$ & \multicolumn{2}{|c|}{ (95\% conf. interval) } \\
\hline Inmeat & .3825135 & .2565291 & 1.49 & 0.376 & -2.876997 & 3.64202 \\
\hline Inalcohol & .0007706 & .1144699 & 0.01 & 0.996 & -1.453708 & 1.45524 \\
\hline -cons & 12.43361 & 2.648824 & 4.69 & 0.134 & -21.22289 & 46.0901 \\
\hline
\end{tabular}

Source: STATA data 
Table 6.

BASIC PRODUCTS (SUGAR, OILS, FLOUR, MILK)

\begin{tabular}{|c|c|c|c|c|c|c|}
\hline Source & SS & df & MS & \multicolumn{3}{|c|}{ Number of obs $=4$} \\
\hline Model & .009993074 & 1 & 009937014 & \multirow{4}{*}{\multicolumn{3}{|c|}{$\begin{aligned} \mathrm{F}(2,1) & =68.73 \\
\text { Prob }>\mathrm{F} & =0.0142 \\
\mathrm{R}-\mathrm{squared} & =0.9717 \\
\text { Adj R-squared } & =0.9576 \\
\text { Root MSE } & =.01202\end{aligned}$}} \\
\hline Residual & .000288997 & 2 & .000144499 & & & \\
\hline Total & .010288991 & 3 & .00340657 & & & \\
\hline & & & & & & \\
\hline InGDP & Coef. & Std. Err. & $\mathrm{t}$ & $\mathrm{P}>\mathrm{t}$ & \multicolumn{2}{|c|}{ (95\% conf. interval) } \\
\hline InVAT & 2.12439 & .2562578 & 8.29 & 0.014 & 1.021808 & 3.226984 \\
\hline -cons & -24.21856 & 4.821549 & -5.02 & 0.037 & -44.96401 & -3.47310 \\
\hline Source & SS & $\mathrm{df}$ & MS & \multicolumn{3}{|c|}{ Number of obs $=4$} \\
\hline Model & 0.00218708 & 2 & .001093542 & \multirow{4}{*}{\multicolumn{3}{|c|}{$\begin{aligned} \mathrm{F}(2,1) & =81.69 \\
\text { Prob }>\mathrm{F} & =0.0779 \\
\text { R-squared } & =0.9939 \\
\text { Adj R-squared } & =0.9818 \\
\text { Root MSE } & =.00365\end{aligned}$}} \\
\hline Residual & .000013554 & 1 & .000013335 & & & \\
\hline Total & .002200443 & 3 & .000733482 & & & \\
\hline & & & & & & \\
\hline InVAT & Coef. & Std. Err. & $\mathrm{t}$ & $\mathrm{P}>\mathrm{t}$ & \multicolumn{2}{|c|}{ (95\% conf. interval) } \\
\hline Insugar & .049145 & .09669084 & 0.51 & 0.701 & -1.182192 & 1.280483 \\
\hline Inmilk & .3910196 & .0587869 & 6.65 & 0.095 & -.3559391 & 1.137978 \\
\hline -cons & 13.755501 & .669165 & 20.56 & 0.031 & 5.252462 & 22.25756 \\
\hline Source & SS & df & MS & \multicolumn{3}{|c|}{ Number of obs $=4$} \\
\hline Model & .00219416 & 2 & 001902794 & \multirow{2}{*}{\multicolumn{3}{|c|}{$\begin{aligned} \mathrm{F}(2,1) & =175.47 \\
\text { Prob }>\mathrm{F} & =0.0533\end{aligned}$}} \\
\hline Residual & $6.2525 \mathrm{e}-06$ & 1 & $6.2525 \mathrm{e}-06$ & & & \\
\hline Total & .00220044 & 3 & .00073348 & \multicolumn{3}{|c|}{ R-squared $=0.9972$} \\
\hline & & & & \multicolumn{3}{|c|}{$\begin{aligned} \text { Adj R-squared } & =0.9915 \\
\text { Root MSE } & =.0025\end{aligned}$} \\
\hline inVAT & Coef. & Std. Err & $\mathrm{t}$ & $\mathrm{P}>\mathrm{t}$ & \multicolumn{2}{|c|}{ (95\% conf. interval) } \\
\hline Inflour & .4713594 & .0462025 & 9.78 & 0.065 & -.141112 & 1.083831 \\
\hline Inoils & .0267159 & .022112 & 1.30 & 0.418 & -.2523706 & .0398025 \\
\hline -cons & 13.11336 & .7557468 & 17.35 & 0.037 & 3.510639 & 22.71604 \\
\hline Source & SS & df & MS & \multicolumn{3}{|c|}{ Number of obs $=4$} \\
\hline Model & .0001714 & 1 & .000171049 & \multirow{4}{*}{\multicolumn{3}{|c|}{$\begin{aligned} \mathrm{F}(2,1) & =0.17 \\
\text { Prob }>\mathrm{F} & =0.7212 \\
\text { R-squared } & =0.0777 \\
\text { Adj R-squared } & =-0.3834 \\
\text { Root MSE } & =.03185\end{aligned}$}} \\
\hline Residual & .0020293 & 2 & .001014223 & & & \\
\hline Total & .0022004 & 3 & .00073340 & & & \\
\hline & & & & & & \\
\hline InVAT & Coef. & Std. Err & $\mathrm{t}$ & $\mathrm{P}>\mathrm{t}$ & \multicolumn{2}{|c|}{ (95\% conf. interval) } \\
\hline Inmilk & -.841218 & 2.046678 & -0.41 & 0.721 & -9.65683 & 7.974913 \\
\hline -cons & 27.34504 & 20.77531 & 1.32 & 0.319 & -62.0439 & 116.734 \\
\hline
\end{tabular}

Source: STATA data 


\section{Conclusions}

This research contributes to fiscal policy making in that the intentional changes in tax rates for product categories were found to have a positive effect. The measures taken on fiscal policy in Kosovo with the change in VAT tax rates and VAT legislation have been shown to be successful.

The taxpayer modulation package according to the econometric model showed that the VAT reduction from $16 \%$ to $8 \%$ along with the increase from $16 \%$ to $18 \%$ on luxury products had a positive effect on the growth of GDP. Also, changes in VAT, made in recent years by the government, suggest that there is much room for improvement in our economy.

To enhance the role and the financial effect as well as the economic effect of Value Added Tax in Kosovo we should continue the VAT increase for luxury goods, services, consumer goods and the better control by the tax authorities. The exemptions from the VAT calculation are as low as possible and the reduction of opportunities for evasion and avoidance. Expansion of the tax base through the reduction of the value added tax threshold, the reduction of the gross margin for VAT payers, in order to bring Kosovo in line with the EU for the VAT threshold. Continuance of joint projects between the two main revenue collection agencies, the Kosovo Tax Administration and Kosovo Customs towards functional integration and VAT collection within the country rather than at the border as it is now. Fulfilment of objectives under the stabilization and association agreement with the EU in the field of taxes and VAT. In conclusion, the taxpayer modulation package according to the econometric model showed that the VAT reduction from 16\% to $8 \%$ and increase from $16 \%$ to $18 \%$ on luxury products had a positive effect on the growth of GDP. Also, changes in VAT, made in recent years by the government, suggest that there much room for improvement in our economy.

\section{Literature:}

Assessment of Public Financial Management, Public expenditure and Financial Accountability (PEFA), the Ministry of Finance of Kosovo, 2008.

Buturac, G. (2014). Država i ekonomija: gdje je Hrvatska?. Ekonomski pregled, 65 (6), $513-540$.

Barro, R. (1990). Government expenditures in a simple endogenous growth model OECD, reports for tax revenues.

Bronchi, C. and A. Burns (2000). "The Tax System in the Czech Republic", OECD economics Department Working Papers, No. 245, OECD Publishing. 
Barbara Jelčić, (1997). Public Finance, Informtor, Zagreb.

Brummerhoff Dieter, (2000). Javne Financije, Sedmo izdanje, Mate d.o.o Zagreb.

Feld, L. P. (2005). Tax Competition: How great is the Challenge?. Ekonomski pregled, 56 (9), 723-758.

G. Asllani, (2014). "Theoretical approaches, techniques and requirements of the tax system".

Genser, B. (2006). The Dual Income Tax: Implementation and Experience in European Countries. Ekonomski pregled, 57 (3-4), 271-288.

G. Asllani, (2012). “The impact of fiscal policy on economic development”, Romania

IMF, WB, MF, CBK and other NSO (2007). The Tax Adminitration of Kosovo. Handbook, Institute for Development Research "Riinvest", (2005) Prishtina.

Jelčić B., (1985). Finance science and finance law, Institute of the textbooks and learning tools Pristine.

Jack M. Mintz: (1999). Growth and taxes, some implications for developing economies, "Public Finance in Developing and Transitional Countries".

Kosovo Customs, www. Dogana.rks-gov.net.

Law no. 04 / L-104, Personal Income Tax as amended (PIT).

Law no. 03 / L-197, on Value Added Tax as amended (VAT).

Law no. 03 / 1-146 on Value Added Tax (VAT).

19. Law no. 04 / 1-102, Tax Administration of Kosovo, as amended (TAK).

M. Gallagher and Ante Babič. (2005).Tax Simplification for Jobs and Growth, Croatia, Philips Gerson (1998). The impact of fiscal policy variables on output growth, IMF WP.

Taxation Trends Report in the Europena Union, edition, 2012

P. Jurkovič, (1191). Designing a tax system to promote structural change. The role of the tax reform in Central and Eastern European Economies, OECD

Rimmler, M., Rose, M. and Zöller, D. (2017). Tax Reform for Tax Competition: Which Alternatives should be Used?. Ekonomski pregled, 56 (11), 1079-1100.

S. Komoni, Public Finance, 2008, Prishtina.

Tax structure and growth: are some taxes better than others? Public choise, Vito, 1900.

Tax Revenues and Economic Growth: (2005). An Empirical Investigation for Greece Using Causality Analysis".

World Bank Group (2009). “A handbook for Tax Simplification”, Washington DC. 


\section{UČINAK PROMJENA POREZA NA DODANU VRIJEDNOST NA FISKALNU STABILNOST KOSOVA}

\section{Sažetak}

Glavni cilj ovog rada je analizirati učinak promjene stopa PDV-a za određene kategorije robe na fiskalnu stabilnost Kosova. PDV na Kosovu je u primjeni od 2001. godine i neizravni je porez na potrošnju koji donosi glavni prihod državnom proračunu. Važnost ovog istraživačkog rada usmjerena je na to jesu li promjene u stopama PDV-a u rujnu 2015. godine imale pozitivne ili negativne utjecaje na neke cijene proizvoda, povećavajući ili smanjujući prihode te kako je to utjecalo na kretanje ekonomskih pokazatelja iskazanih kroz BDP. Metodologija rada temelji se na usporednoj analizi podataka iz primarnih i sekundarnih izvora. Ekonometrijski model uključuje dvije varijable i njihove odnose, (nezavisna varijabla - PDV i zavisna varijabla - BDP). Kroz ekonometrijski model i linearnu regresijsku analizu za razdoblje 2013.-2016., hipoteze su testirane pomoću STATA kako bi se utvrdio utjecaj promjena stope PDV-a na proračun, gospodarski rast i ekonomski razvoj. Rezultati analize pokazuju da je smanjenje PDV-a sa $16 \%$ na $8 \%$ za osnovne proizvode i povećanje PDV-a sa $16 \%$ na $18 \%$ na luksuzne proizvode, imao pozitivan učinak na prihode i rast BDP-a Kosova.

Ključne riječi: stopa PDV-a, proračunski prihodi, ekonomski rast, oporezivanje 